\title{
学会印象記
}

\section{東大・大気海洋研・共同利用研究集会 「海洋生物のさまざまな適応戦略」に参加して}

浦 野 明 央 (北海道大学・名誉教授)
E-mail: aurano@sci.hokudai.ac.jp

本年の6月21日から 22 日にかけて開催された標記の 研究集会は、「体液調節の分子生物学」「体液調節の多様 性と普遍性」「境界動物の内分泌現象」「内分泌現象の進 化」というセッションからなっていた。

3番目までのセッションの初めは、順に、近々に退職 を迎える東工大の広瀬茂久先生、富山大の内山実先生、 新潟大学の野崎真澄先生、そして最後のセッションは少 し前に還暦を迎えた早稲田大学の筒井和義先生の、ライ フワークを踏まえた基調講演で、いずれも聞き応えのあ る素晴らしい内容であった。それぞれのセッションでの、 基調講演に続く中堅あるいは若手の講演もなかなか充実 したものであった。とは言っても、気にならなかったこ とがまったくなかったという訳ではない。

気になったことの中には、筆者が現役時代に問題だと 思いながら解決できずに、蓋をしたまま通り過ぎてきた ことが多々あった。今回、素晴らしい仕事を話してくれ た研究者達なら、何とかしてくれるだろうとの期待も込 めて、以下にそれを記した。

もっとも気になったのは、この研究集会の夕イトルで ある「海洋生物のさまざま適応戦略」にどれだけ迫って いるのか、という点である。自然の中で生きている野生 動物のライフサイクルは、まさに適応戦略である。筆者 が研究してきたサケの母川回帰の場合、冬のアラスカ湾 から秋に溯上する母川に至るまでに、生体内でどのよう なことが起きているか知らなければ話は始まらない。サ ケと逆の産卵回遊をするウナギの場合、少なくとも川か ら海に出ていく時にどのようなことが起きているのか分 かっていなければ、ウナギの海洋への適応戦略は語れな いのではないかと思いながら講演を聴かせてもらった次 第である。

ライフサイクルに関連してもう1つ気になっているこ とは、人為的な実験、例えば海水あるいは淡水への、強 制的な動物の移行である。ウナギの場合なら、産卵回遊 のために海に降ろうとしている時に、浸透圧調節機構に 何が起きているかを知ることが、本来の比較生理学なの
ではないだろうか。

実験なりフィールドで採取した試料の解析方法でも、 気になりながら放置してきたことがある。遺伝子の発現 を定量的に解析し、それをもとに生理現象を説明するた めには、まずターゲットにした遺伝子の転写速度と転写 産物の分解速度、すなわち mRNAの夕ーンオーバーを 見積もる必要がある。qPCRで相対的に mRNAの残存量 を測定しても、生理現象との関係を知ることはできない。 遺憾ではあるが、筆者の現役時代には、この問題を解決 する術を見い出せなかった。

遺伝子の発現という言葉は、広義には翻訳まで含むし、 生理機能に実際に携わるのはタンパク質であるから、翻 訳されてできてくるタンパク質についても、ターンオー バーを知ることが大切である。下垂体の場合、ホルモン mRNAの量、下垂体のホルモン含量、および血中のホ ルモン濃度は、必ずしもパラレルに変動していないので ある。ホルモン受容体にも同様の問題があることは自明 であろう。それに加えて、ぞれだけ機能的(結合活性を もつという意味で) な受容体が発現しているのかを知る ことも重要である。

最後に一言ふれておきたいのは、比較内分泌学が、ぞ れだけ最近の生物科学のトレンドを念頭においているの か、である。同一の組織が多様な細胞からできているこ とから、単一細胞についての分子生物学的な解析がふつ うになってきた。一方、今回の研究集会で理研の工樂樹 洋博士が指摘しているように、ゲノムデータの利用には いろいろな問題があるので、次世代シーケンサーの利用 には細心の注意が必要である。

今回のテーマのように、試料の入手が困難で研究に時 間がかかることが多い野生動物の比較内分泌学では、ど れだけ先を見て研究を進めるかが重要である。さもない と、努力して研究を進めても、結果が出た時には時代遅 れということになってしまい、分野がジリ貧状態になり かねないのである。 